\title{
Evolution of the uniquely adaptable lentiviral envelope in a natural reservoir host
}

\author{
LJ Demma ${ }^{\dagger 1,2}$, TH Vanderford ${ }^{\dagger 1}$, JM Logsdon $\mathrm{Jr}^{3}, \mathrm{MB}$ Feinberg ${ }^{4,5}$ and \\ SI Staprans*4,6
}

\begin{abstract}
Address: ${ }^{1}$ Program in Population Biology, Evolution and Ecology, and Emory Vaccine Center, Emory University, Atlanta, GA, USA, ${ }^{2}$ Centers for Disease Control and Prevention, Division of Bacterial and Mycotic Diseases, 1600 Clifton Road, Mailstop D-63, Atlanta, GA 30333, USA, ${ }^{3}$ Department of Biology, Emory University, Atlanta, GA. Current address: University of Iowa, Department of Biological Sciences, Roy J. Carver Center for Comparative Genomics, 301 Biology Building, Iowa City, IA 52242, USA, ${ }^{4}$ Departments of Medicine and Microbiology and Immunology, and Emory Vaccine Center, Emory University School of Medicine, Atlanta, GA, USA, ${ }^{5}$ Merck Vaccine Division, Merck and Company, Inc., 770 Sumneytown Pike, West Point, PA 19486, USA and 'Emory Vaccine Center, 954 Gatewood Rd., Atlanta, GA, 30329, USA
\end{abstract}

Email: LJ Demma - lqd1@cdc.gov; TH Vanderford - thvande@emory.edu; JM Logsdon - john-logsdon@uiowa.edu; MB Feinberg - mark_feinberg@merck.com; SI Staprans* - sstapr2@sph.emory.edu

* Corresponding author †Equal contributors

Published: 20 March 2006

Retrovirology2006, 3:19 doi:10.1186/1742-4690-3-19

This article is available from: http://www.retrovirology.com/content/3/1/19

(C) 2006Demma et al; licensee BioMed Central Ltd.

This is an Open Access article distributed under the terms of the Creative Commons Attribution License (http://creativecommons.org/licenses/by/2.0), which permits unrestricted use, distribution, and reproduction in any medium, provided the original work is properly cited.
Received: 30 January 2006

Accepted: 20 March 2006

\begin{abstract}
Background: The ability of emerging pathogens to infect new species is likely related to the diversity of pathogen variants present in existing reservoirs and their degree of genomic plasticity, which determines their ability to adapt to new environments. Certain simian immunodeficiency viruses (SIVcpz, SIVsm) have demonstrated tremendous success in infecting new species, including humans, resulting in the HIV-I and HIV-2 epidemics. Although SIV diversification has been studied on a population level, the essential substrates for cross-species transmission, namely SIV sequence diversity and the types and extent of viral diversification present in individual reservoir animals have not been elucidated. To characterize this intra-host SIV diversity, we performed sequence analyses of clonal viral envelope (env) VIV2 and gag P27 variants present in individual SIVsm-infected sooty mangabeys over time.
\end{abstract}

Results: SIVsm demonstrated extensive intra-animal VIV2 length variation and amino acid diversity (le38\%), and continual variation in VIV2 N-linked glycosylation consensus sequence frequency and location. Positive selection was the predominant evolutionary force. Temporal sequence shifts suggested continual selection, likely due to evolving antibody responses. In contrast, gag P27 was predominantly under purifying selection. SIVsm VIV2 sequence diversification is at least as great as that in HIV-I infected humans, indicating that extensive viral diversification in and of itself does not inevitably lead to AIDS.

Conclusion: Positive diversifying selection in this natural reservoir host is the engine that has driven the evolution of the uniquely adaptable SIV/HIV envelope protein. These studies emphasize the importance of retroviral diversification within individual host reservoir animals as a critical substrate in facilitating cross-species transmission. 


\section{Background}

Most newly emerging human pathogens are zoonotic [1], yet little is known about the natural reservoirs from which these zoonoses emerge. RNA viruses, due to their extraordinary genomic variability, have been particularly capable of establishing infection in new host species [1-5]. As examples, the transfer of avian influenza A [6-8] and rodent hantavirus [9-12] from their natural reservoirs to create novel human outbreaks has been documented on several occasions $[13,14]$. Nonetheless, successful breaching of the host range barrier is relatively rare, with self-sustaining outbreaks in a new host species presumably requiring multiple mutational events. Two different simian immunodeficiency viruses (SIVs) from Central African chimpanzees and West African sooty mangabeys (SM) are inferred to have been transferred to humans by several independent zoonotic events, resulting in the introduction to humans of HIV-1 and HIV-2, respectively [15-18]. Although phylogenetic analyses of SIV sequences reveal considerable viral genetic diversity between different infected individuals [19], the magnitude of intra-animal viral diversity, the substrate for selection in cross-species transmission events, has not been studied. Furthermore, the mechanisms and tempo of the generation of viral variation in natural reservoir hosts are poorly understood.

Over 40 different species of African non-human primates harbor the CD4+ T cell tropic lentiviruses [20]. In these natural reservoir hosts, the SIVs do not cause AIDS, despite high viremia. Disease only develops upon transmission of SIV to new non-natural hosts such as humans or Asian macaques [21]. We have been studying the virologic and immunologic aspects of natural SIV infection in a colony of SIV-infected SMs at the Yerkes National Primate Research Center [22-24]. Although SIV-infected SMs are highly viremic, they manifest far lower levels of aberrant immune activation and apoptosis than are seen in pathogenic SIV and HIV infections and maintain preserved T lymphocyte populations and regenerative capacity $[22,23]$. Studies of the SIVsm viral variants obtained from different SMs demonstrate magnitudes of inter-animal viral diversity similar to that observed with different HIV-1 group M subtypes [19].
Variation in the viral surface proteins of zoonotic viruses is likely key to the ability of these agents to engage new host cell receptors and gain a foothold in new species. For influenza virus, amino acid changes and changes in glycosylation patterns in the viral hemagglutinin affect receptor binding specificity and host range $[25,26]$. For the SARS coronavirus (SARS-CoV) discreet variations in the spike protein are proposed to be important for viral tropism and animal-to-human transmission [27]. The HIV and SIV envelope (Env) proteins are extraordinarily genetically variable and highly glycosylated. HIV Env has evolved to tolerate considerable aa sequence flexibility, including variation in $\mathrm{N}$-glyc sites, and to conformationally shield key receptor-binding domains [28]. This genetic and functional flexibility enables Env to escape from antibody responses and to utilize different co-receptors to gain efficient entry into target cells [29-35]. In our studies of the adaptation of SIVsm from a naturally infected SM to a new simian host (rhesus macaques) we observed that one of three phylogenetically distinct env variants could replicate to high levels in the newly infected macaques. These variants encoded a shorter variable region 1 loop and lacked two specific N-linked glycosylation sites ( $\mathrm{N}$-glyc sites) [24]. The pre-existence of viral $e n v$ variants in naturally infected SMs that are capable of replicating to high levels in a new host species pointed to the importance of SIVsm diversity in the reservoir host in enabling cross-species transmission.

Studies of zoonotic RNA virus diversity have not focused on the variation that already exists in the source reservoir hosts; rather, the focus has largely been on the genetic variation and specific adaptive mutations that are observed in the newly emerged human pathogen [36,37]. While adaptive mutations are critical for efficient host-to-host propagation in the newly-infected species, viral diversity that is already extant in reservoir hosts is another important source of the genetic variation necessary for successful cross-species transmission. Here we describe extraordinarily high intra-host SIVsm env V1V2 diversity in naturally infected SMs, maintained by its high replication rate and positive selection most likely mediated by antibody responses. Ongoing evolution of an extremely mutable SIV env in the natural host explains the ease with which

Table I: Summary of animals used in this study. Data was collected from five sooty mangabeys used in this study (housed at Yerkes Primate Research Center, Atlanta, GA).

\begin{tabular}{lccccc}
\hline Animal Name & Virus subtype & Birthdate & $\begin{array}{c}\text { Mean Viral Load } \\
\text { (copies/mL) }\end{array}$ & No. VIV2 clones & No. gag clones \\
\hline FFj & 1 & $04-20-88$ & $2.11 \times 10^{6}$ & 46 & 48 \\
FBo & 2 & $07-18-91$ & $1.86 \times 10^{6}$ & 73 & 23 \\
FDo & 3 & $07-29-91$ & $1.67 \times 10^{6}$ & 52 & 24 \\
FJo & 1 & $08-18-91$ & $8.92 \times 10^{5}$ & 91 & 43 \\
FQi & 1 & $05-20-87$ & $1.04 \times 10^{6}$ & 9 & 43 \\
\hline
\end{tabular}




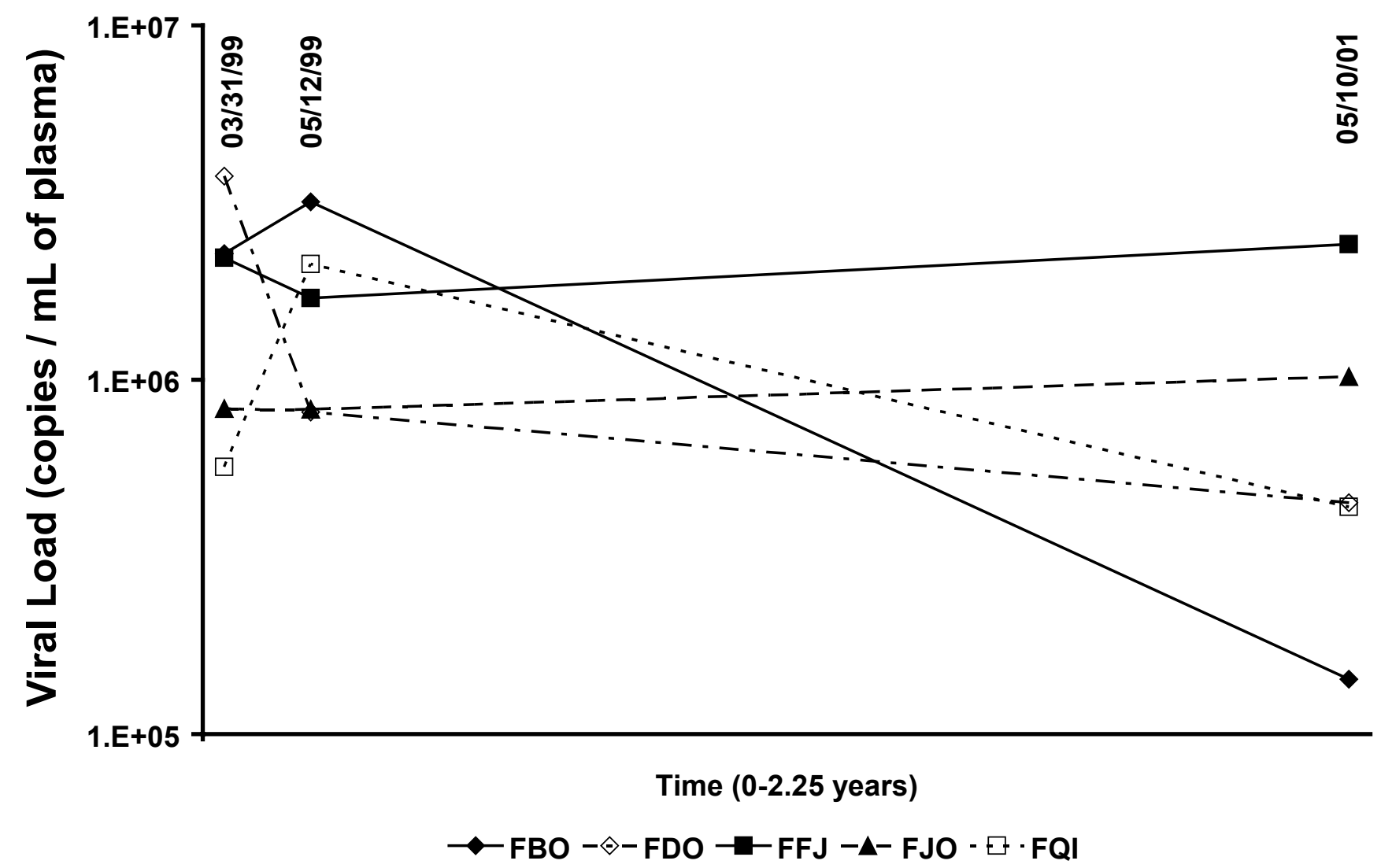

Figure I

Viral load quantification for five naturally infected sooty mangabeys. Viral RNA in plasma obtained in 3/99, 5/99, and $5 / 0$ I was measured by a real-time RT-PCR assay designed to quantitatively detect the diverse SIVsm variants (viral RNA copies/mL).

these lentiviruses can adapt to divergent host cellular environments and evade $\mathrm{Ab}$ responses in new host species.

\section{Results}

Magnitude of intra-host SIVsm diversity in naturally infected SMs

Five naturally SIV-infected SMs (Table 1) were sampled three times over a 2 -year period. Viral RNA in plasma obtained in 3/99,5/99, and 5/01 was measured by a realtime RT-PCR assay designed to quantitatively detect the diverse SIVsm variants [23]. Time points were chosen so that evolution could be assessed over both shorter and longer time intervals. Viral load averaged $1.5 \times 10^{6} \mathrm{SIV}$ RNA copies/ml plasma, and fluctuated modestly over the 2 -year period (Figure 1). No clinical signs of AIDS were observed in any of the infected SMs over the study period.

Multiple V1V2 env clones (range 15-29) and p27 gag clones (range 5-19) were sampled from each animal at each time point (Genbank Accession numbers AY733102AY733566). Env and gag were chosen for analysis since they were thought to represent the extremes of diversity in SIV populations. These genes also differ in how the immune system detects them, with env V1V2 being exposed primarily to neutralizing antibodies [38] and gag p27 being recognized mostly through cellular immune responses [39]. The number of individual viral sequences analyzed (Table 1) combined with the sampling of variants over a short time interval ( 2 months) and a longer time interval ( 2 years) exceeds that reported in previous studies of SIV diversity in natural hosts [40-43].

To characterize the overall evolutionary dynamics of natural SIV variation, we built maximum likelihood trees of both env V1V2 (Figure 2A) and gag p27 (Figure 2B) sequences. The SIVsm variants from each SM formed distinct clades in both genes, and the env and gag trees showed the same relationship between virus populations of the 5 animals. These results demonstrate that each host harbors a phylogenetically distinct population of SIVs, presumably as the result of infection with distinct viral populations and subsequent host-specific viral evolution. 

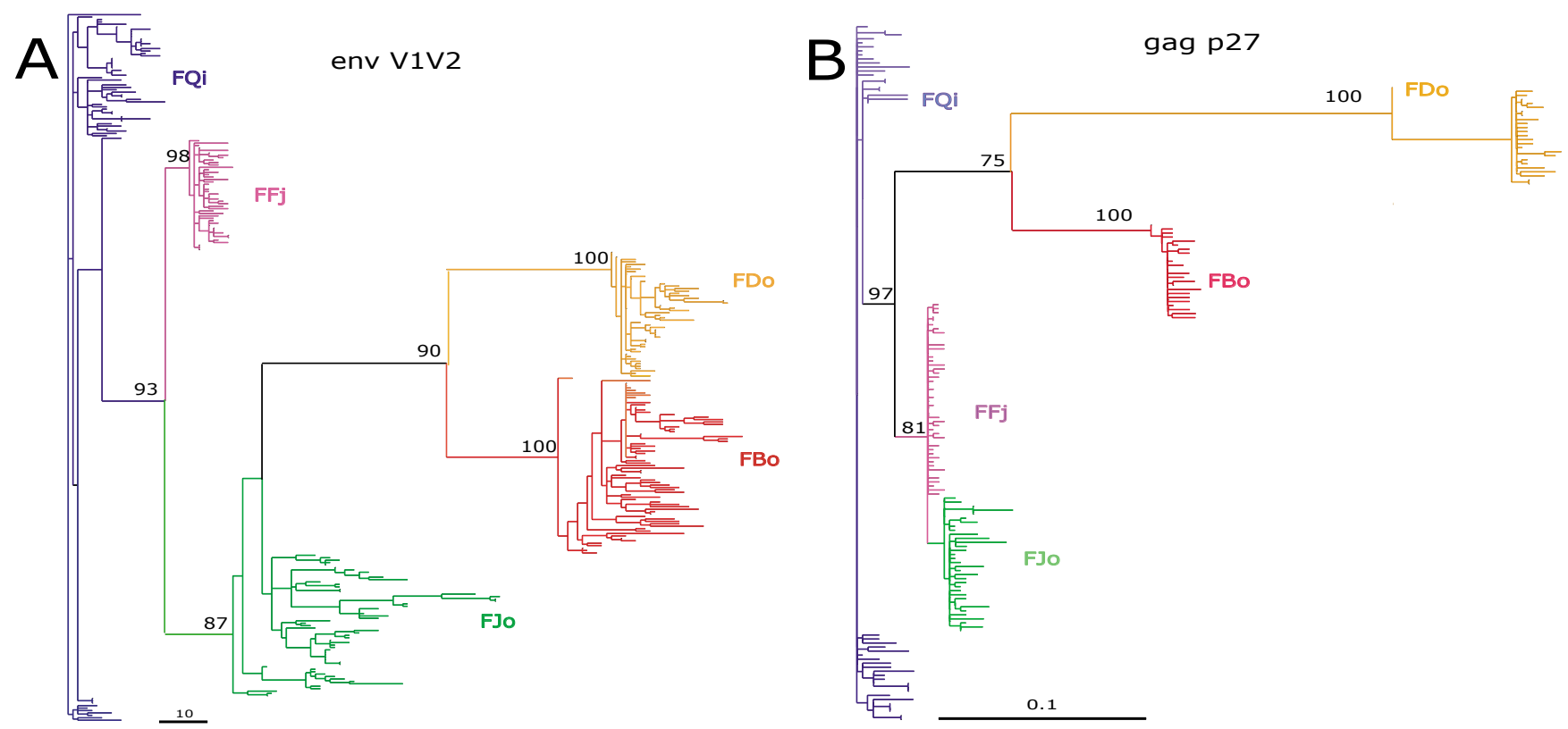

Figure 2

Maximum likelihood trees of (A) all VIV2 variants, and (B) all gag variants. A GTR model of evolution with empirically determined substitution rates was assumed. Bootstrap support is shown only for major lineages.

The translated env aa sequences (FJo, Figure 3; data from all animals can be obtained from THV) demonstrate significant V1V2 heterogeneity, including heterogeneity in

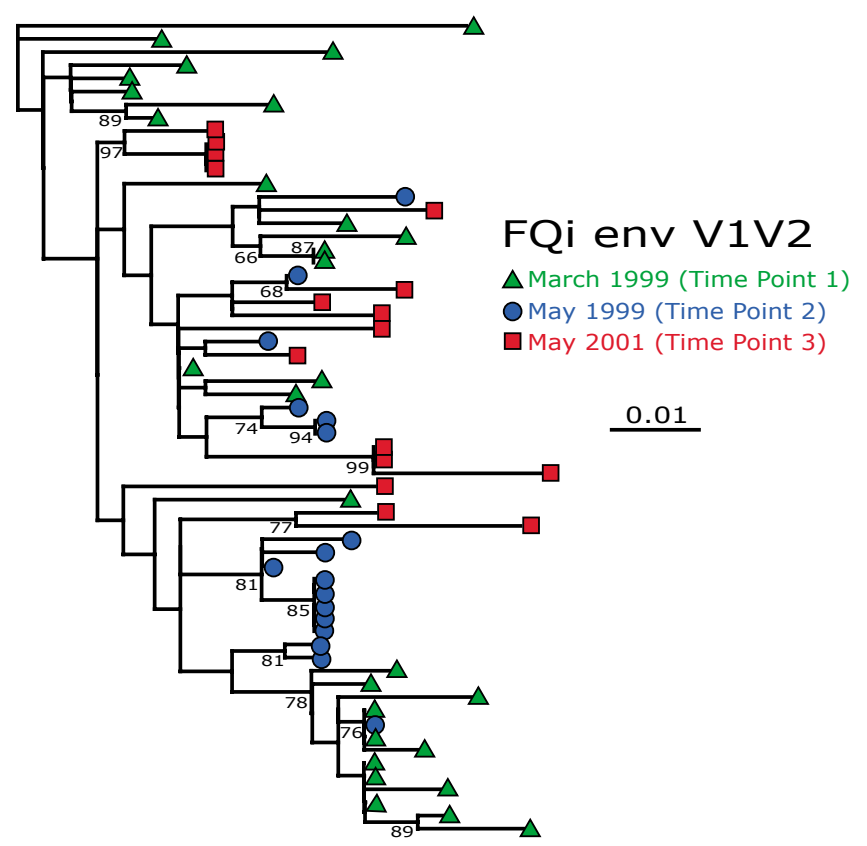

Figure 4

Maximum likelihood tree of FQi. VIV2 variants using the GTR $+\Gamma+I$ model of substitution. $>60 \%$ bootstrap support is indicated on the tree. numerous predicted N-glyc sites (NXS/T, where X can be any aa but proline). Considerable V1 length variations were observed (Table 2 and for example, Figure 3), such that alignment of this region required manual adjustment, and may not represent precise homology. There were no trends in V1V2 sequence length variation over time (data not shown). Gag aa alignments (available from THV) showed significantly less aa variation reflecting its highly conserved nature.

Pairwise nt and aa diversity was calculated after removing regions of uncertain homology (gap-stripping) in V1, such that the values obtained for intra-host diversity represent minimum values. Average pairwise aa diversity was high in env V1V2 (average: 5.6\%, range: 0 and 37.7\%; Table 1) and low in gag p27 (average 1\%; range: 0 and $7.1 \%$, data not shown). The minimal diversity detected in gag, which was amplified under identical conditions, confirms that the observed V1V2 diversity is not the result of PCR-introduced mutation. In individual animals, the magnitude of nt and aa diversity did not change significantly over the 2-year observation period (Table 2). However, there appeared to be animal-to-animal variation in the extent of V1V2 diversity, with animals FFj and FDo exhibiting lower V1V2 nt and aa diversity than FJo and FBo (ANOVA $\mathrm{p}<0.01$, with Bonferroni adjustment). $\mathrm{Nt}$ and aa diversity were not correlated with viremia, suggesting that mechanisms other than or in addition to the magnitude of virus replication determine the extent of viral diversity. We cannot rule out that reduced diversity in FFj 
Table 2: Summary of intra-animal amino acid and nucleotide diversity and sequence length in VIV2 env. Pairwise distances were calculated using the Gamma distance method with gamma shape parameter of 0.3 in the program Mega 2.0 b. Shown are the mean, standard deviation, maximum, and minimum pairwise amino acid and nucleotide diversity and mean, maximum and minimum amino acid sequence length for each animal, at each time point.

\begin{tabular}{|c|c|c|c|c|c|c|c|}
\hline Animal & Date & $\begin{array}{c}\text { Diversity (aa) } \\
\text { (Min, Max) }\end{array}$ & St Dev (aa) & $\begin{array}{c}\text { Diversity (nt) } \\
\text { (Min, Max) }\end{array}$ & St Dev (nt) & $\begin{array}{c}\text { Length (aa) } \\
\text { (Min, Max) }\end{array}$ & $\begin{array}{c}\text { \# N-glyc sites } \\
\text { (Min, Max) }\end{array}$ \\
\hline \multirow[t]{3}{*}{ FQi } & $3-99$ & $0.097(0,0.21)$ & 0.047 & $\mathbf{0 . 0 5 I}(0,0.115)$ & 0.024 & $\begin{array}{c}\text { I 42. I I (140, } \\
\text { | } 45)\end{array}$ & $6.6(5,9)$ \\
\hline & $5-99$ & $0.067(0,0.13)$ & 0.037 & $\mathbf{0 . 0 3 3}(0,0.065)$ & 0.018 & $\begin{array}{c}\text { | } 4 \text { I.4 | ( } 140 \\
\mid 44)\end{array}$ & 7.I $(5,9)$ \\
\hline & $5-01$ & $0.087(0,0.18)$ & 0.037 & $\mathbf{0 . 0 4 7}(0,0.107)$ & 0.017 & $\begin{array}{c}\text { I } 42.64(140 \\
\mid 44)\end{array}$ & $7.9(6,9)$ \\
\hline \multirow[t]{3}{*}{ FDo } & $3-99$ & $\begin{array}{c}0.041(0.01 \\
0.09)\end{array}$ & 0.018 & $\begin{array}{c}0.021(0.006 \\
0.042)\end{array}$ & 0.009 & $\begin{array}{c}\text { | } 43.77(142 \\
\mid 45)\end{array}$ & $8.4(8,9)$ \\
\hline & $5-99$ & $0.033(0,0.07)$ & 0.014 & $\begin{array}{c}0.020(0.003 \\
0.042)\end{array}$ & 0.008 & $\begin{array}{c}\text { | } 43.53(14 \mid \\
\mid 45)\end{array}$ & $8.5(7,9)$ \\
\hline & $5-01$ & $0.059(0,0.11)$ & 0.024 & $\begin{array}{c}0.029(0.003 \\
0.059)\end{array}$ & 0.011 & $\begin{array}{c}144.89 \\
(141.149)\end{array}$ & $7.5(4,9)$ \\
\hline \multirow[t]{3}{*}{ FJo } & $3-99$ & $\begin{array}{c}0.123(0.02 \\
0.26)\end{array}$ & 0.052 & $\begin{array}{c}0.063(0.006 \\
0.128)\end{array}$ & 0.026 & $\begin{array}{c}156.83(148 \\
163)\end{array}$ & $7.9(6,10)$ \\
\hline & $5-99$ & $0.076(0,0.18)$ & 0.050 & $\mathbf{0 . 0 4 5}(0,0.113)$ & 0.028 & $\begin{array}{c}148.43(145 \\
\text { I53) }\end{array}$ & $6.1(6,7)$ \\
\hline & $5-01$ & $0.160(0,0.38)$ & 0.082 & $\mathbf{0 . 0 8 8}(0,0.177)$ & 0.041 & $\begin{array}{c}\text { I } 50.26(144 \\
\mid 52)\end{array}$ & $6.1(3,7)$ \\
\hline \multirow[t]{3}{*}{ FBo } & $3-99$ & $0.086(0,0.2)$ & 0.041 & $0.045(0,0.101)$ & 0.020 & $\begin{array}{c}147.16(137 \\
156)\end{array}$ & $6.6(5,8)$ \\
\hline & $5-99$ & $\begin{array}{c}0.1 \mathrm{I} 8(0.0 \mathrm{I} \\
0.3 \mathrm{I})\end{array}$ & 0.047 & $\begin{array}{c}0.058(0.003 \\
0.136)\end{array}$ & 0.022 & $\begin{array}{c}146.64(137 \\
|5|)\end{array}$ & $6.9(6,8)$ \\
\hline & $5-01$ & $0.110(0,0.21)$ & 0.047 & $0.053(0,0.102)$ & 0.022 & $\begin{array}{c}147.61(142 \\
153)\end{array}$ & $6.6(6,8)$ \\
\hline \multirow[t]{3}{*}{$\mathbf{F F j}$} & $3-99$ & $0.029(0,0.08)$ & 0.015 & $\mathbf{0 . 0 1 7}(0,0.035)$ & 0.007 & $\begin{array}{c}141.39(140 \\
145)\end{array}$ & $7.8(7,8)$ \\
\hline & $5-99$ & $0.051(0,0.11)$ & 0.023 & $\mathbf{0 . 0 2 4}(0,0.046)$ & 0.010 & $\begin{array}{c}141.42(133 \\
\mid 45)\end{array}$ & $7.8(7,8)$ \\
\hline & $5-01$ & $0.032(0,0.07)$ & 0.018 & $\begin{array}{c}0.016(0.006 \\
0.031)\end{array}$ & 0.006 & $\begin{array}{c}\text { I } 44.83(14 \mid \\
\mid 49)\end{array}$ & $7.6(6,8)$ \\
\hline
\end{tabular}

and FDo are the result of infection with less diverse virus populations.

\section{Positive selection maintains env VIV2 diversity}

Although the magnitude of sequence diversity did not change over time, it was likely that env sequences at later time points had diverged from those sampled earlier. To investigate the temporal pattern of sequence evolution within each animal, all available samples from all three time-points for each animal were pooled and analyzed by maximum likelihood (Fig. 4; FQi). Sixteen of the nineteen (85\%) bootstrap-supported clades from FQi contain variants from a single time point only. This pattern was repeatable amongst variants from all other animals; $100 \%, 80 \%, 69 \%$, and $63 \%$ of bootstrap supported clades consisted of a single time point in animals FDo, FFj, FJo, and FBo, respectively. In an analysis of random trees, the number of matching time-point sequences that comprise a monophyletic group showed a Poisson distribution; $86 \%$ of variants did not form monophyletic clades with any other matching time-point variant (i.e., these sequences stood alone). Thus, the observed temporal clustering of SIVsm viral populations does not occur by chance alone (Kolmogorov-Smirnov test, $\mathrm{p}<0.01$ ).

Temporal phylogenetic structure in V1V2 suggested that continual V1V2 diversification was occurring. To look for evidence of positive selection, $\mathrm{dN}$ and $\mathrm{dS}$ were calculated at each site and averaged over a 3-codon sliding window for VIV2 (Fig. 5A) or 30-codon sliding window for p27 (Fig. 5B). These results confirmed that $d N-d S>0(p=$ 0.003 , t-test) in V1 (aa's 25-55) in all animals, indicating positive selection. For p27, the same test showed that $\mathrm{dS}>\mathrm{dN}$ along this gene ( $\mathrm{t}$-test, $\mathrm{p}<0.001$ ), indicating that purifying selection limits its diversity. V1 was consistently found to be under significant positive selection in all animals, except FFj (data not shown). By contrast, the few aa changes in p27 sequences in the different animals over time appeared random in nature except for a single partially fixed mutation in FDo. 


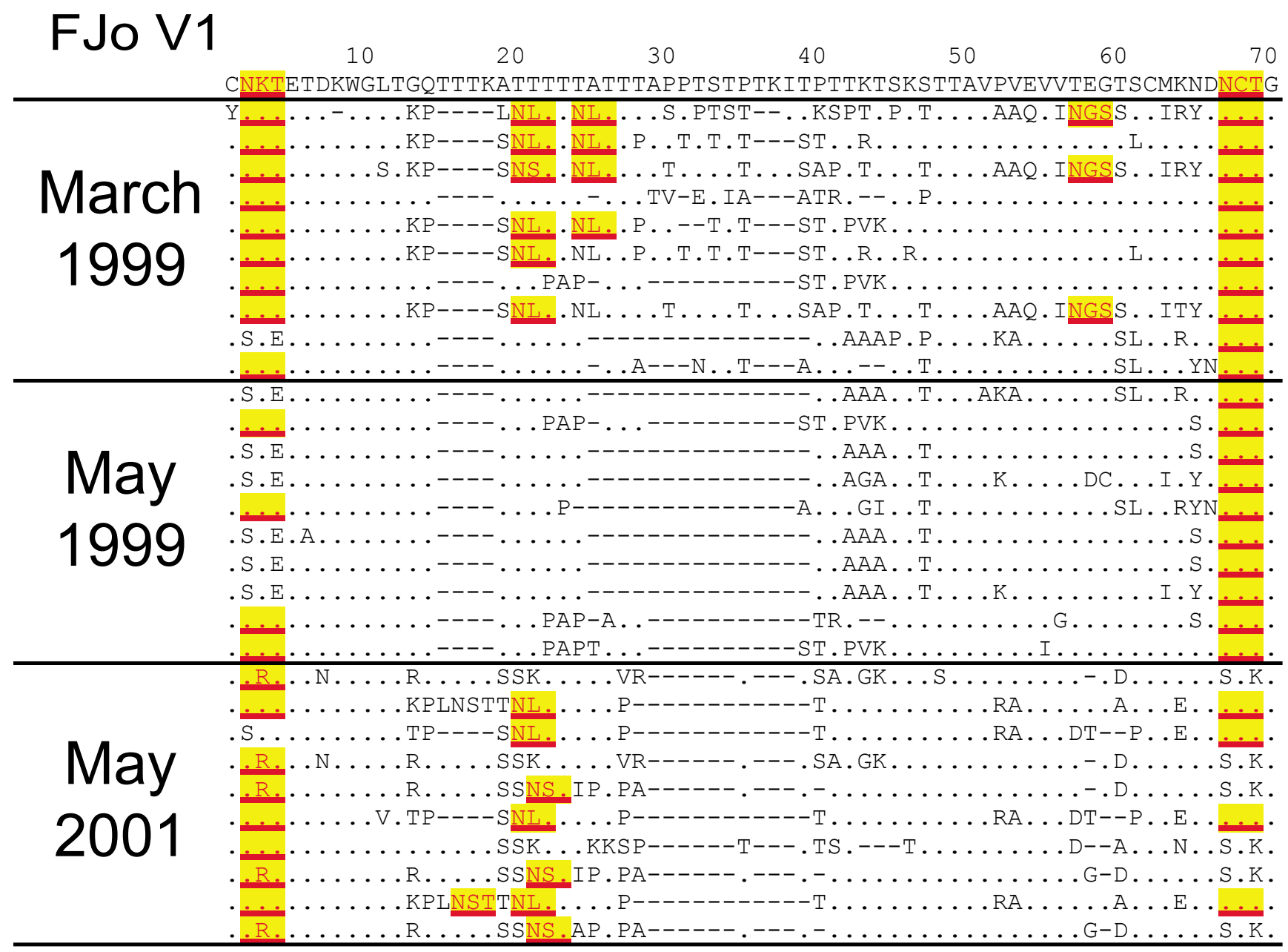

\section{Figure 3}

Env amino acid diversity of FJo SIVsmm sequences. The consensus of all sequences is indicated at the top with the amino acid positions labeled above. Time points I (3I-March-99), 2 (I2-May-99) and 3 (I0-May-0I) are indicated by I, 2, and 3 in the sequence titles. The glycosylation consensus motifs (NXT/S) are highlighted in yellow.

\section{SIVsm env VIV2 sequences predict a highly glycosylated protein, with $\mathbf{N}$-glyc site density being inversely correlated with Env diversification}

Up to $10 \mathrm{~N}$-glyc sites are contained within the SIVsm V1V2 regions sequenced in this study. In multiple locations overlapping consensus motifs (aa's 42-44, 52-54, and 95-107) are present, such that the exact site of glycosylation varies (Fig. 3). These overlapping consensus motifs are in particularly diverse regions of V1V2 and in regions of strong positive selection.

V1V2 clones from the five SMs contained variable numbers of $\mathrm{N}$-glyc sites, ranging from 3 to 10. The average number of $\mathrm{N}$-glyc sites among all animals was 7.2. There was no clear pattern of increased or decreased V1V2 env glycosylation with time. However, the mean number of $\mathrm{N}$-glyc sites for FFj and FDo (7.8 and 8.2, respectively) was significantly higher than the other animals (average between 6.5 and 6.9; ANOVA, Tukey B, p < 0.001). An additional $\mathrm{N}$-glyc site is found in $\mathrm{V} 1$ in the majority of sequences in FFj and FDo at position 45, but not in the other animals. There was also a smaller range of $\mathrm{N}$-glyc sites per set of sequences in FFj and FDo (6-9) compared to other animals (3-10). As described, the FDo and FFj SIVsm populations were less diverse and had lower average $\mathrm{dN}$ compared to the virus populations found in the other 3 animals (Table 2). A significant inverse correlation between the mean number of $\mathrm{N}$-glyc sites and both pairwise nt diversity and nonsynonymous substitutions was observed when combining data from all five SMs ( $\mathrm{p}<$ 0.001, Fig. 6). 

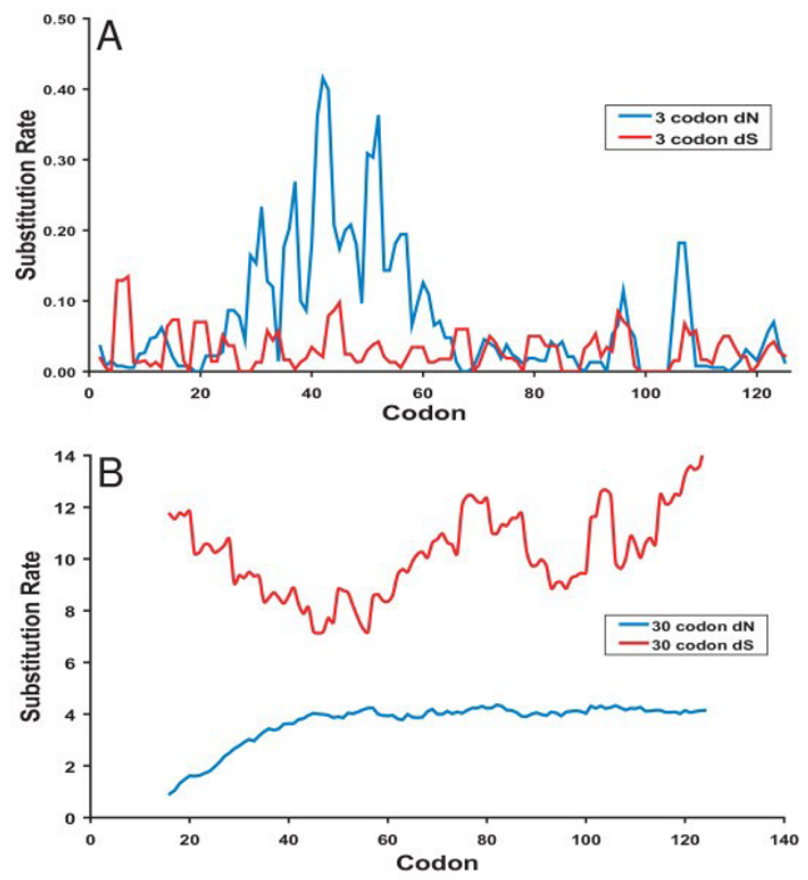

\section{Figure 5}

Modes of selection in VIV2 and gag. (A) Positive selection $(\mathrm{dN}>d \mathrm{~d})$ in env $\mathrm{VI}$ and $(\mathrm{B})$ purifying selection $(\mathrm{dN}<\mathrm{dS})$ in gag p27 within animal FQi is shown through a sliding window analysis of nonsynonymous and synonymous substitution rate.

\section{Comparable levels of lentiviral env VIV2 diversification in SIVsm-infected natural hosts and HIV-infected humans}

Diversification of the HIV genome in humans underlies its success in evading pharmacologic and immunologic selection pressures, and likely facilitates human-tohuman transmission events. It has also been suggested that extensive virus diversification actually drives disease progression and the destruction of the immune system $[44,45]$. To compare the SIVsm genome diversity observed in natural hosts with that of HIV-1 in humans, longitudinally sampled $e n v$ aa sequences from proviral DNA representing 9 untreated, chronically HIV-infected humans [46] were compared to our plasma RNA-derived SIVsm env data. Two time points were chosen from both the SM and the human dataset so that the interval between observations was approximately 2.5 years.

For the comparison of nucleotide sequence diversity, homologous regions surrounding V1V2 were aligned and gap-stripped. Average pairwise nucleotide diversity was calculated separately in each host at both time points (Figure 7A). Measures of SIVsm and HIV-1 nt diversity were not significantly different from each other within each time point (Figure 7B; p > 0.05, Mann-Whitney U test). Thus SIVsm V1V2 sequence diversity in the natural SM host is at least as great as, if not greater than that observed in HIV-1-infected humans, especially given that the archival nature of proviral sequences may overestimate the diversity of the actively replicating viral RNA population [47-49].

Env adapts not only through raw nt sequence variability, but also through variation in both sequence length and $\mathrm{N}$ glyc site density and position. Substantial changes in these phenotypic parameters will affect the ability of env to utilize different co-receptors $[50,51]$, evade neutralizing antibodies $[52,53]$ and establish new infections in naïve hosts $[54,55]$. To elucidate differences in SIVsm and HIV-1 V1V2 sequence length and $\mathrm{N}$-glyc site density variation, a pooled estimate of variance within each species was compared. Neither the variances of sequence length nor glycosylation density differed significantly between species at time point 1 although although humans had a greater variance in both parameters at time point $2\left(\mathrm{~F}_{\max }\right.$ test, $\mathrm{p}<$ $0.01)$. The variance of sequence length of SIVsm V1 decreased between the two time points $\left(\mathrm{F}_{\max }\right.$ test, $\mathrm{p}<$ 0.005 ) suggesting that the magnitude of selection in SMs shifts over time, while in humans the variance remained stable (Figure 7C). The variation in glycosylation density (Figure 7D-E) remained relatively stable over time within both species except for a slight but non-significant expansion of variance in humans at time point 2 .

\section{Discussion}

To identify viral characteristics that may explain how the SIVs have successfully infected other primate species, we analyzed the types and extent of SIVsm diversification in naturally infected SMs. Our findings of high intra-host extremes of SIVsm V1V2 nt diversity extend previous studies of naturally SIV-infected SMs and African green monkeys (AGMs) [56-63] by demonstrating that viruses found within a single animal can vary by greater than $35 \%$ at the aa level. The ranges of aa diversity in some intra-host pairwise SIVsm V1V2 sequence comparisons in this study rival that of inter-animal comparisons [40]. As our diversity calculations exclude V1V2 length variation, they represent an underestimate of the true magnitude of viral diversity. V1V2 length polymorphisms would be predicted to have dramatic effects on SIVsm Env conformation and phenotypic diversity $[64,65]$.

Positive selection in V1V2 appears to explain the observed env diversification. Specific sites in V1 were consistently selected for in four of the five animals. Our results agree with other studies of SIV and HIV selection, in which dN$\mathrm{dS}$ was consistently greater than 0 [66-68]. However, the majority of previous studies of nonpathogenic SIV infection $[56,69,70]$ calculated $\mathrm{dN}$ and $\mathrm{dS}$ by averaging over all sites, obscuring variation in selective pressure between aa sites. In addition to positive selection in V1V2, we 


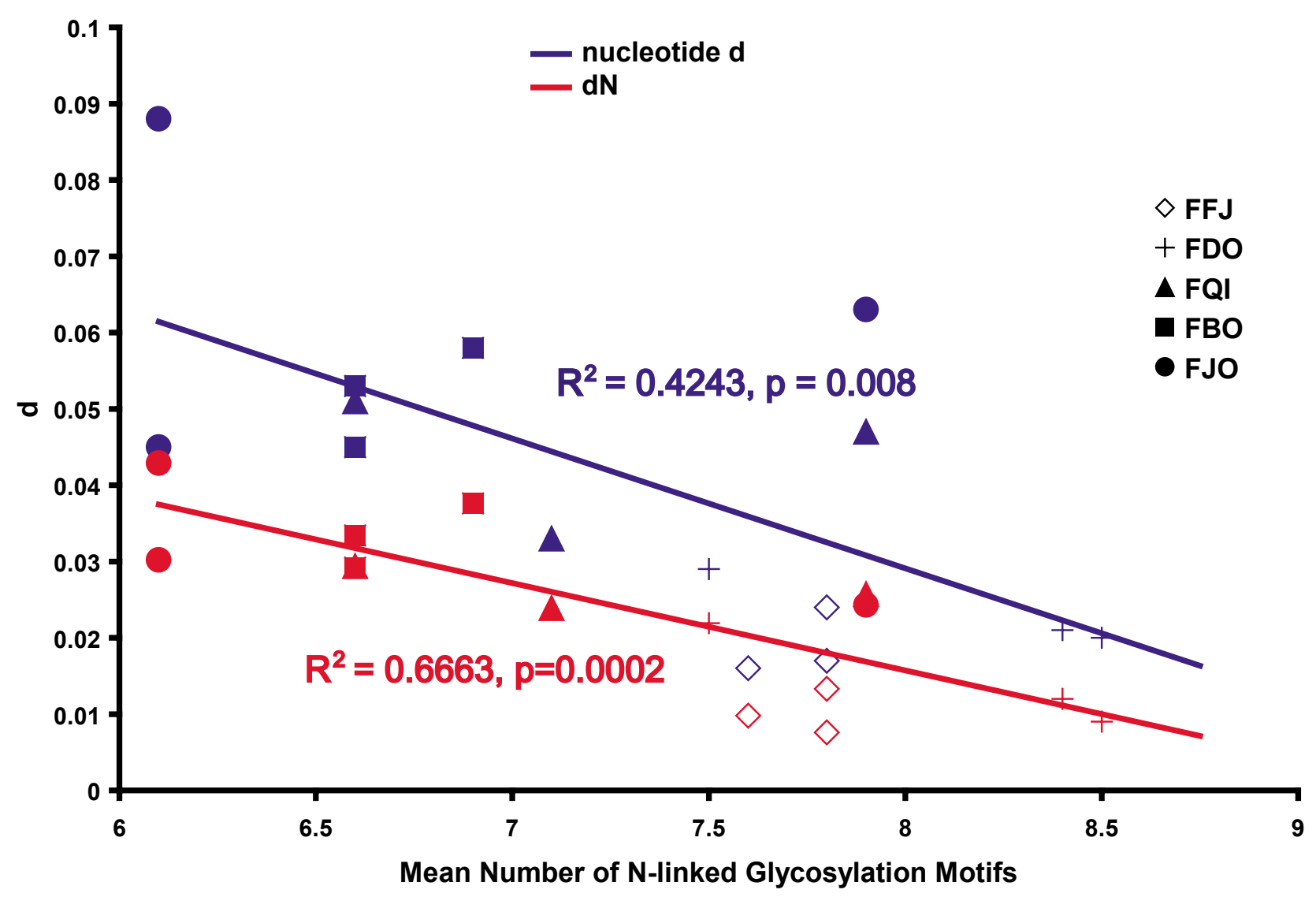

Figure 6

Glycosylation of SIVsmm VIV2 is inversely correlated with pairwise nucleotide diversity.

detected temporal shifts in SIVsm populations, some of which involved the gain or loss of N-glyc sites.

Beyond aa sequence variation, the extensive glycosylation of the HIV and SIV envelope glycoprotein is thought to reduce protein epitope exposure and to facilitate viral evasion of antibody neutralization $[28,52,53,55]$. Ten potential N-glyc sites were recognized in the SIVsm V1V2 region, with the average virus encoding $7.2 \mathrm{~N}$-glyc sites. The neutralization resistant SIVmac239 strain contains 8 predicted glycosylation sequences in the same region, while some other macaque-adapted SIVs appear to have fewer N-glyc sites, especially in the V1 region [28]. Thus, like SIVcpz in a naturally infected chimpanzee [71], SIVsm appears to be highly glycosylated in naturally infected SMs. Presumably, continually evolving antibody responses in these natural hosts maintain a highly glycosylated surface protein, albeit without effectively suppressing virus replication. Our observation of an inverse relationship between $\mathrm{N}$-glyc site density and SIVsm V1V2 sequence diversity might result from the more highly gly- cosylated viral variants being better shielded from the diversifying selection pressures of anti-SIV antibodies than less glycosylated variants, as recently suggested for HIV [55]. Thus, antibody-mediated pressures on the SIVsm envelope glycoprotein appear to exist in this natural host reservoir species, and serve to continually select for adaptations in envelope sequence and structure.

In contrast to env, SIVsm gag p27 was under strong purifying selection in infected SMs. Temporal analyses of gag p27 demonstrated no evidence of the fixation of specific aa substitutions, suggesting that gag p27 is not the target of strong selective pressures such as those that might be expected if anti-Gag cellular immune responses were present. These observations corroborate our findings that natural SM hosts mount limited cellular immune responses to SIV infection [22,23,72].

Comparison of our SIVsm plasma RNA-derived V1V2 sequences and a set of HIV-1 envelope sequences obtained from proviral DNA [46], while not the ideal 
A

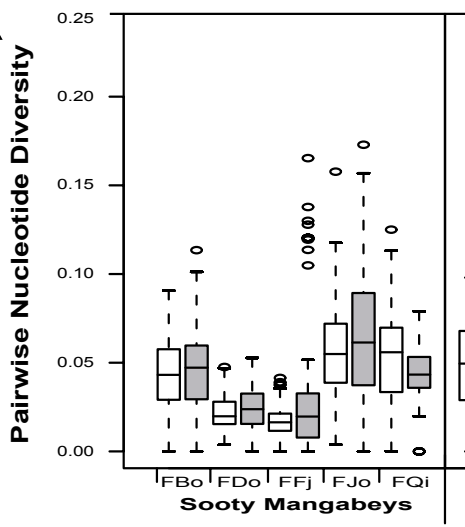

C

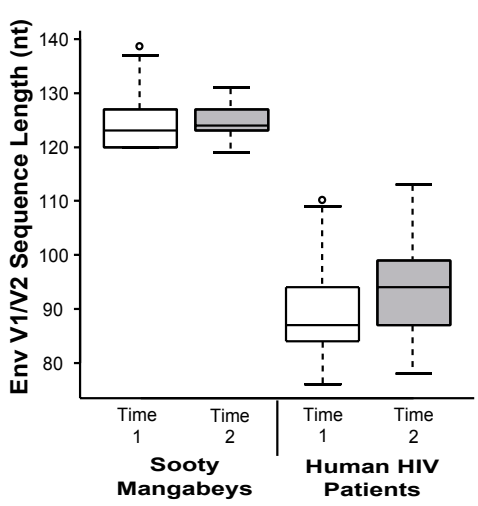

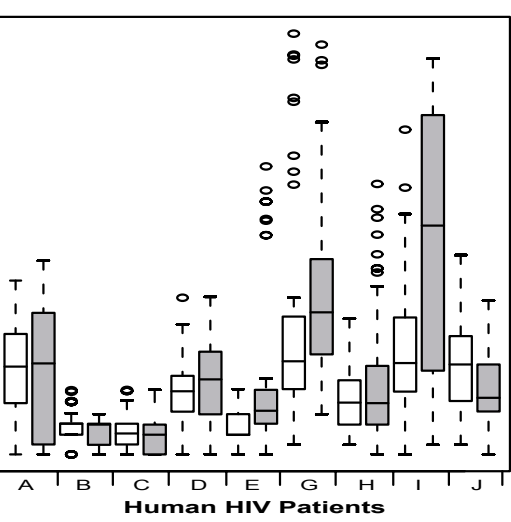

Human HIV Patients

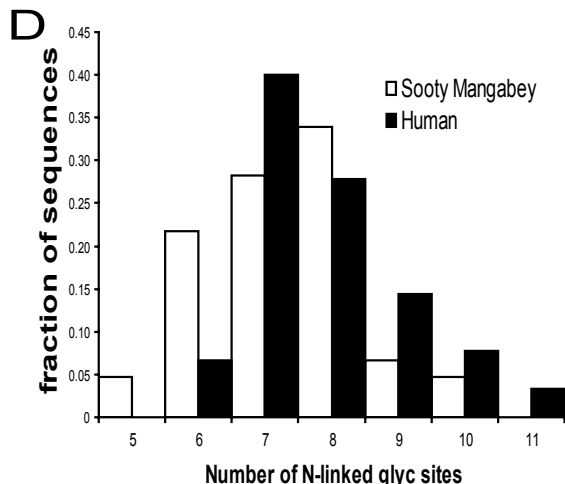

$\mathrm{B}$

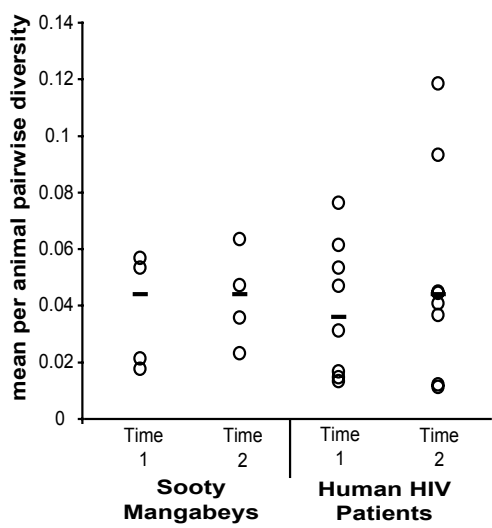

E

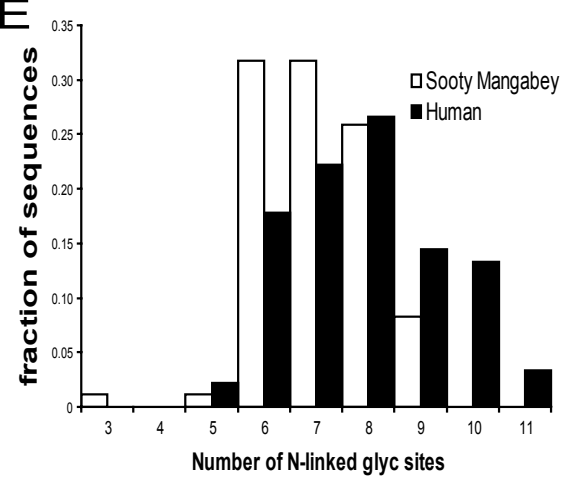

Figure 7

Comparison of SIVsm and HIV-I VIV2 sequences. Longitudinal SIVsm and HIV-I env sequences were aligned and homologous regions were compared with respect to nucleotide diversity, sequence length, and glycosylation density at an early time point (Time I) and a time point approximately 2.5 years later (Time 2). (A) Standard box and whisker plots of the distributions of intra-animal pairwise nucleotide diversity. Time $I$ is in white, time 2 is in gray, and circles represent outliers of the distribution. (B) Intra-animal average pairwise diversity at each time point. Median values are indicated with a slash. (C) Standard box and whisker plots of intra-animal env VIV2 sequence length at each time point. (D) and (E) N-linked glycosylation sites at time I and time 2, respectively. SMs are in white and humans are in black.

comparison, demonstrates that natural SIVsm V1V2 diversity is as great, if not greater than that observed in HIV-1infected humans. Since average pairwise diversity is an indirect measure of viral effective population size [73], these results suggest that an equivalent number of target cells are infected in both SM and human immunodeficiency virus infections. The similar levels of viral variation may also indicate that selective forces acting on env V1V2 are comparable in both SIVsm-infected natural mangabey reservoir hosts and in HIV-infected humans. A caveat of these SIV and HIV sequence comparisons is that this protein is quite divergent between the two viruses, and it is possible that this region of $e n v$ could be under different functional and immune selection pressures in the two hosts.

As V1V2 is primarily a target of the antibody response, it will be important to more thoroughly characterize in natural hosts SIVsm variation in viral genome regions known to encode multiple cytotoxic T lymphocyte (CTL) epitopes in non-natural hosts (such as humans and macaques). Such studies could help to elucidate the selective pressures exerted by the natural host on other genome regions and inform us as to the potential for genetic plasticity in viral genes that are targeted by current CTL-focused HIV vaccine strategies.

The observation that high-level virus replication and extensive sequence diversification do not harm SMs is consistent with the notion that the direct effects of SIV replication are not sufficient to explain AIDS [44,45,74]. Instead, our studies of natural host responses to infection indicate that indirect mechanisms, such as host inflammatory immune responses elicited by virus infection, likely play a role in the development of AIDS in new nonnatural hosts $[22,23]$. Because the humoral immune responses in naturally infected SMs do not significantly suppress virus replication, they may actually serve to pro- 
mote the continuous selection of env sequences and structures [75]. This helps to explain how the unique SIV/HIV Env structure has evolved in lower primates, resulting in a virus that is extremely difficult to neutralize [75,76]. This continuous diversifying selection pressure likely also serves to generate variants with expanded cell tropisms that are well suited to adapt to new host cellular environments [24]. For instance, a spectrum of variant SIV Env conformations with differing requirements for the levels of CD4 on target cells might help to breach species differences in CD4 molecules, which are generally not as well conserved as the viral co-receptors such as CCR5 $[77,78]$. Thus, high viral variability and recombination within a natural reservoir host or host population will increase the likelihood that variants with the ability to replicate in new host species exist. The ongoing intra-host diversification of human-adapted RNA viruses, such as HIV and hepatitis $\mathrm{C}$ virus, enables these viruses to continually respond to changing pressures, such as those imposed by immune responses and antiviral therapies, making treatment of these human diseases a formidable challenge $[52,79,80]$.

\section{Conclusion}

The extent of intra-host SIVsm env diversification in its natural reservoir likely underlies the ease with which certain SIVs infect new host species [20,24]. As new human pathogens emerge, much focus is placed on viral evolution in the newly infected hosts, such as adaptive mutations that facilitate robust replication and pathogenesis. However, our studies of SIVsm demonstrate that an important source of viral variation and thus adaptive potential can be found within the viral populations of individual reservoir host animals. This extensive intra-animal viral variation, which is likely key to facilitating crossspecies transmission events, may be a common zoonotic signature among diverse emergent pathogens.

\section{Materials and methods Specimens and RT-PCR}

Five age-matched, naturally SIV-infected SMs from the colony at the Yerkes National Primate Research Center, Atlanta, GA were chosen for study. Individual animals were between 8 and 12 years of age and were estimated to have been infected for approximately 3 to 9 years, based on available HIV-2 seroconversion data. Thus, all animals were born in, and acquired their SIVsmm infection in, captivity. Group housing of the animals confounds identification of potential donor-recipient pairs. Plasma from animals FQi, FJo, FFj, FDo, and FBo was obtained on 313-99, 5-12-99, and 5-10-01 and viral RNA was extracted and quantified using a real-time RT-PCR assay designed to quantitatively detect the diverse SIVsmm variants [23]. Viral RNA was diluted such that approximately 2500 copies of viral RNA were used in a Superscript ${ }^{\mathrm{TM}}$ First-Strand Synthesis System for RT-PCR (Invitrogen Corporation,
Carlsbad, CA.), following the protocol provided, primed by random hexamers. $2 \mu \mathrm{L}$ of cDNA from the RT-PCR was used for PCR amplification of both $e n v$ V1V2 and gag p27 with Qiagen HotStar Taq (Qiagen Inc., Chatsworth, CA.). The env V1V2 region was amplified with the forward primer V1V2DF (5'-TTTGATGCNTGGAAYAAYAC-3') corresponding to bp 6774-6792 of the SIVsmmH4 genome (GenBank accession no. $\underline{\text { X14307) }}$, and the reverse primer V1V2DR (5'-CATAGCATCCCARTARTGCTT-3') corresponding to bp 7217-7238 of the SIVsmmH4 genome. The primer pair amplified a $421 \mathrm{bp}$ fragment spanning the V1-V2 hypervariable region of envelope. The gag region was amplified using shortgagF1 (5'TTAAGTCCAAGAACATTAAATGC-3') and shortgagR (5'GTAGAACCTGTCTACATAGCT-3') which correspond to bp 1493-1515 and 19371957 of SIVsmmH4, respectively, yielding a 421 bp product of the 5' end of the p27 capsid protein. Primers were designed by choosing highly conserved regions from an alignment of all SIV and HIV2 env and gag sequences from the HIV sequence database [81]. Conditions for each reaction were $30 \mathrm{~min}$. at $50^{\circ} \mathrm{C}, 15 \mathrm{~min}$. at $95^{\circ} \mathrm{C}$, followed by 40 cycles of $94^{\circ} \mathrm{C}$ for $1 \mathrm{~min}$., $52^{\circ} \mathrm{C}$ for $30 \mathrm{~s}$, and $72^{\circ} \mathrm{C}$ for $1 \mathrm{~min}$. A final extension time was carried out for $5 \mathrm{~min}$. at $72^{\circ} \mathrm{C}$. No-template controls and negative controls from the RNA extraction were used in each set of reactions, both RT and PCR, to ensure that no cross contamination occurred at either step. RT-PCR sensitivity was determined to be $=500$ copies per reaction.

\section{Cloning and DNA sequencing}

PCR products from each sample were run on a $1.5 \%$ lowmelt agarose gel. The resulting 425 bp V1V2 or 421 bp gag product was extracted and cloned into the pCR4-TOPO vector (TOPO TA Cloning Kit, Invitrogen). From Rodrigo et al. [82] it was determined that if 2500 copies of viral RNA are used in the RT-PCR reaction, 20 clones picked from the PCR product will be unique. Therefore, approximately 20 clones from V1V2 and 10 from gag (due to lower expected diversity in this conserved gene) at each time point and each animal were randomly selected and sequenced using the M13F and M13R primers using the dye terminator cycle sequencing method with an $\mathrm{MJ}$ Research automated sequencer.

\section{Sequence and phylogenetic analyses}

Sequences were aligned using the program CLUSTAL X [83], followed by manual adjustment using MacClade 4.0 [84] and BioEdit Sequence Alignment Editor [85]. Nonaligned regions of length variation in V1 and V2 were removed (corresponding to nucleotides 6932-6974), and sequences containing internal stop codons or frame shifts were also excluded from analysis as these are thought to be PCR artifacts [86]. 
For tree construction, the Modeltest program [87] was used to construct and evaluate the DNA substitution models used. Based on the Modeltest results phylogenetic analysis on sequences obtained from successive time points during the acute infection was performed by maximum likelihood (ML) using the program Treefinder [88]. The general-time-reversible model, which allows for rate variation between sites [89-91], was used, and the shape parameter $(\alpha)$ of the gamma distribution used in this model was estimated, as were base frequencies and substitution rate parameters. Bootstrap support was determined with 1,000 resamplings of the ML tree using distance methods in PAUP4.0b10*, incorporating the estimated rate parameters. Phylogenetic trees were constructed from all clones obtained from V1V2 and gag and also separately on V1V2 and gag sequences obtained from each animal at each time point by maximum likelihood (ML) using the program Treefinder.

The cumulative number of nonsynonymous $(\mathrm{dN})$ and synonymous (dS) nucleotide substitutions was estimated using SNAP, Synonymous/Non-synonymous Analysis [81] which calculates rates of nucleotide substitution based on the method of Nei and Gojobori [92], and incorporating a statistic developed in Ota and Nei [93]. Viral diversity at each time point was determined by calculating the pairwise nucleotide distances for each of the clones using the method of Tamura and Nei [94], and pairwise amino acid distances using the Gamma distance method in the program MEGA 2.1 [95]. Average dN and dS were calculated using the modified Nei-Gojobori method in MEGA 2.1. Phylogenetic trees constructed with synonymous or nonsynonymous sites only were constructed in MEGA 2.1 using distance methods, incorporating the Tamura-Nei model of nucleotide substitution with gamma-distributed rates. All statistics were computed using SYSTAT 10.

\section{Temporal analysis of VIV2 sequences from individual animals}

In order to show that viral populations do not vary randomly through time, random trees of all variants from each animal were generated and the number of matching time-point sequences that formed a monophyletic clade was counted for each random tree. For the random trees, the number of matching time-point sequences that comprise a monophyletic group are Poisson distributed. The Kolmogorov-Smirnov test was used to compare our observed trees with those built from randomly sampled sequences.

\section{Comparison of SIVsm and HIV-I diversity}

Env nt sequences from 9 patients of a study of 10 HIVinfected patients [46] were compared to our SIVsm env data with respect to nt diversity, sequence length varia- tion, and predicted N-linked glycosylation site diversity. For V1V2 nt diversity comparisons, sequences from both SMs and patients were aligned and stripped of gaps. Pairwise estimates of intra-host nt diversity were calculated using Mega 2.1 [96]. For sequence length variation, alignments (including gaps) of both SIVsm and HIV-1 were pared down to the V1V2 region as defined by the flanking regions of extreme conservation. For this test, homology of each amino acid site was not as important as the overall homology of the region. Mean-squared error variance was determined by ANOVA in R [97] for both glycosylation density and sequence length in each species at each time point. Variances were compared manually using an $\mathrm{F}_{\max }$ test.

\section{Data deposition footnote}

Genbank Accession Nos: $\underline{\text { AY733102-AY733566 }}$

\section{Abbreviations}

SIV, simian immunodeficiency virus; SM, sooty mangabey; RM, rhesus macaque; nt, nucleotide; aa, amino acid; $\mathrm{Ab}$, antibody; $\mathrm{NAb}$, neutralizing antibody.

\section{Competing interests}

The author(s) declare that they have no competing interests.

\section{Authors' contributions}

LJD, MBF, and SIS conceived and designed the experiments. LJD carried out the reverse transcription, PCR, and cloning. JML contributed reagents and manpower for sequencing. LJD, THV, and JML conceived and performed statistical and phylogenetic analyses of the sequence data. LJD, THV, and SIS wrote the manuscript. All authors read and approved the final manuscript.

\section{Acknowledgements}

We dedicate this paper to the memory of Dr. H. McClure, for his selfless devotion to advancing AIDS research in the nonhuman primate models, and for his genuine and warm collegiality. We also thank Drs. F. Novembre and S. Garg for assistance with serologic and virologic measures, and Dr. B. Korber for helpful discussions. This work was supported by grant Al49I5502 to M.B.F, and RR00I65 to the Yerkes Primate Center and NIAID Statistical Training on AIDS Grant T32-AI07442.

\section{References}

I. Woolhouse ME): Population biology of emerging and reemerging pathogens. Trends Microbiol 2002, 10:S3-S7.

2. Mahy BW]: Human viral infections: an expanding frontier. Antivir Res 1997, 36:75-80.

3. Domingo E: Viruses at the edge of adaptation. Virology 2000, 270:25I-253.

4. Domingo E, Holland Jj: Mutation rates and rapid evolution of RNA viruses. In Evolutionary Biology of Viruses Edited by: Morse SS. New York, Raven Press; 1994:161-184.

5. Lucas M, Karrer U, Lucas A, Klenerman P: Viral escape mechanisms-escapology taught by viruses. Int J Exp Path 2001, 82:269-286. 
6. Matrosovich M, Krauss S, Webster RG: H9N2 influenza A viruses from poultry in Asia have human virus-like receptor specificity. Virology 200I, 28I: I56-162.

7. Webby RJ, Webster RG: Emergence of influenza A viruses. Phil Trans R Soc Lond B 200I, 356:1817-1828.

8. Skehel JJ, Wiley DC: Receptor binding and membrane fusion in virus entry: the influenza hemagglutinin. Ann Rev Biochem 2000, 69:53I-569.

9. Morzunov SP, Rowe JE, Ksiazek TG, Peters C], St. Jeor SC, Nichol ST: Genetic analysis of the diversity and origin of hantaviruses in Persomyscus luecopus mice in North America. J Virol 1998, 72:57-64.

10. Hughes AL, Friedman R: Evolutionary diversification of proteincoding genes of hantaviruses. Mol Biol Evol 2000, I7:1558-1568.

II. Feuer R, Boone JD, Netski D, Morzunov SP, Jeor SCS: Temporal and spatial analysis of sin nombre virus quasispecies in naturally infected rodents. J Virol I999, 73(II):9544-9554.

12. Hughes JM, Peters CJ, Cohen ML, Mahy BWJ: Hantavirus pulmonary syndrome: an emerging infectious disease. Science 1993 , 262:850-85I.

13. Childs JE, Ksiazek TG, Spiropoulou CF, Krebs JW, Morzunov S, Maupin GO, Gage KL, Rollin PE, Sarisky J, Enscore RE: Serologic and genetic identification of Peromyscus maniculatus as the primary rodent reservoir for a new hantavirus in the southwestern United States. J Infect Dis 1994, 169:1271-1280.

14. Parrish CR, Kawaoka Y: The origins of new pandemic viruses: the acquisition of new host ranges by canine parvovirus and influenza A viruses. Ann Rev Microbiol 2005, 59(I):553-586.

15. De Cock KM: Epidemiology and the emergence of human immunodeficiency virus and acquired immune deficiency syndrome. Phil Trans $R$ Soc Lond B 200I, 356:795-798.

16. Sharp PM, Bailes E, Gao F, Beer BE, Hirsch VM, Hahn BH: Origins and evolution of AIDS viruses: estimating the time-scale. Biochem Soc Trans 2000, 28:275-282.

17. Sharp PM, Bailes E, Robertson DL, Gao F, Hahn BH: Origins and evolution of AIDS viruses. Biol Bull 1999, 196:338-342

18. Lemey P, Pybus OG, Wang B, Saksena NK, Salemi M, Vandamme AM: Tracing the origin and history of the HIV-2 epidemic. Proc Natl Acad Sci USA 2003, 100:6588-6592.

19. Apetrei C, Kaur A, Lerche NW, Metzger M, Pandrea I, Hardcastle J, Falkenstein S, Bohm R, Koehler J, Traina-Dorge V, Williams T, Staprans S, Plauche G, Veazey RS, McClure H, Lackner AA, Gormus $B$, Robertson DL, Marx PA: Molecular epidemiology of simian immunodeficiency virus SIVsm in U.S. primate centers unravels the origin of SIVmac and SIVstm. I Virol 2005, 79(14):899|-9005.

20. Apetrei C, Robertson DL, Marx P: The history of SIVs and AIDS: epidemiology, phylogeny and biology of isolates from naturally SIV infected non-human primates (NHP) in Africa. Front Biosci 2004, 9:225-254.

21. Hahn BH, Shaw GM, Cock KMD, Sharp PM: AIDS as a zoonosis: scientific and public health implications. Science 2000, 287:607-6/4.

22. Silvestri G, Fedanov A, Germon S, Kozyr N, Kaiser W, Garber D, McClure H, Feinberg MB, Staprans SI: Divergent host responses during primary SIVsmm infection of natural mangabey and non-natural rhesus macaque hosts. J Virol 2005, 79:4043-4054.

23. Silvestri G, Sodora DL, Koup RA, Paiardini M, O'Neil SP, McClure HM, Staprans SI, Feinberg MB: Non-pathogenic simian immunodeficiency virus infection of sooty mangabey mokeys is characterized by limited bystander immunopathology despite chronic high-level viremia. Immunity 2003, I 8:44I-452.

24. Demma LJ, Logsdon JMJ, Vanderford TH, Feinberg MB, Staprans SI: SIV quasispecies adaptation to a simian new host. PLoS Path 2005, I ( I):e3.

25. Ilyushina N, Rudneva I, Gambaryan A, Bovin N, Kaverin N: Monoclonal antibodies differentially affect the interaction between the hemagglutinin of $\mathrm{H} 9$ influenza virus escape mutants and sialic receptors. Virology 2004, 329(I):33-39.

26. Suzuki Y: Sialobioloogy of influenza: molecular mechanism of host range variation of influenza viruses. Biol Pharm Bull 2005, 28(3):399-408.

27. Qu XX, Hao P, Song XJ, Jiang SM, Liu YX, Wang PG, Rao X, Song HD, Wang SY, Zuo Y, Zheng AH, Luo M, Wang HL, Deng F, Wang HZ, Hu ZH, Ding MX, Zhao GP, Deng HK: Identification of two critical amino acid residues of the severe acute respiratory syn- drome coronavirus spike protein for its variation in zoonotic tropism transition via a double substitution strategy. J Biol Chem 2005, 280(33):29588-29595.

28. Zhang M, Gaschen B, Blay W, Foley B, Haigwood N, Kuiken CL, Korber $B$ : Tracking global patterns of $\mathbf{N}$-linked glycosylation site variation in highly variable viral glycoproteins: HIV, SIV, and HCV envelopes and influenza hemagglutinin. Glycobiology 2004, 1 4:1229-1246.

29. Chackerian B, Rudensey LM, Overbaugh J: Specific N-linked and O-linked glycosylation modifications in the envelope VI domain of simian immunodeficiency virus variants that evolve in the host alter recognition by neutralizing antibodies. J Virol 1997, 7 I ( I0):7719-7727.

30. Reiter JN, Means RE, Desrosiers RC: A role for carbohydrates in immune evasion in AIDS. Nat Med 1998, 4:679-684.

31. Quinones-Kochs MI, Buonocore L, Rose JK: Role of N-linked glycans in a human immunodeficiency virus envelope glycoprotein: effects on protein function and the neutralizing antibody response. J Virol 2002, 76:4199-42II.

32. Ohgimoto S, Shioda T, Mori K, Nakayama EE, Hu H, Nagai Y: Location-specific, unequal contribution of the $\mathbf{N}$ glycans in simian immunodeficiency virus gp/20 to viral infectivity and removal of multiple glycans without disturbing infectivity. J Virol 1998, 72:8365-8370.

33. Kinsey NE, Anderson MG, Unangst TJ, Joag SV, Narayan O, Zink MC, Clements JE: Antigenic variation of SIV: mutations in V4 alter the neutralization profile. Virology 1996, $231: 14-21$.

34. Kwong PD, Doyle ML, Casper DJ, Cicala C, Leavitt SA, Majeed S, Steenbeke TD, Venturi M, Chaiken I, Fung M, Katinger H, Parren PWIH, Robinson J, Van Ryk D, Wang L, Burton DR, Freire E, Wyatt R, Sodroski J, Hendrickson WA, Arthos J: HIV-I evades antibodymediated neutralization through conformational masking of receptor-binding sites. Nature 2002, 420:678-682.

35. Cheng-Mayer C, Brown A, Harouse JM, Luciw PA, Mayer Al: Selection for neutralization resistance of the simian/human immunodeficiency virus SHIVsf33a variant in vivo by virtue of sequence changes in the extracellular envelope glycoprotein that modify N-linked glycosylation. J Virol 1999, 73(7):5294-5300.

36. Holmes KV: Structural biology. Adaptation of SARS coronavirus to humans. Science 2005, 309(5742): 1822-1823.

37. Antia R, Regoes RR, Koella JC, Bergstrom CT: The role of evolution in the emergence of infectious diseases. Nature 2003, 426(6967):658-661.

38. Frost SDW, Wrin T, Smith DM, Pond SLK, Liu Y, Paxinos E, Chappey C, Galovich J, Beauchaine J, Petropoulos CJ, Little SJ, Richman DD: Neutralizing antibody responses drive the evolution of human immunodeficiency virus type I envelope during recent HIV infection. Proc Natl Acad Sci USA 2005, I02(5I): $185 \mid 4-18519$.

39. Yusim K, Kesmir C, Gaschen B, Addo MM, Altfeld M, Brunak S, Chigaev A, Detours V, Korber BT: Clustering patterns of cytotoxic T-lymphocyte epitopes in human immunodeficiency virus type I (HIV-I) reveal imprints of immune evasion on HIV-I global variation. Journal of Virology 2002, 76:8757-8768.

40. Beer BE, Bailes E, Dapolito G, Campbell BJ, Goeken R, Axthelm MK Markham PD, Bernard J, Zagury D, Franchini G, Sharp PM, Hirsch V: Patterns of genomic sequence diversity among their simian immunodeficiency viruses suggest that L'Hoest monkeys (Cercopithecus Ihoesti) are a natural lentivirus reservoir. J Virol 2000, 74(8):3892-3898

4I. Beer BE, Bailes E, Goeken R, Dapolito G, Coulibaly C, Norley SG, Kurth R, Gautier JP, Gautier-Hion A, Vallet D, Sharp PM, Hirsch V: Simian immunodeficiency virus (SIV) from sun-tailed monkeys (Ceropithecus solatus): evidence for host-dependent evolution of SIV within the C. I'hoesti superspecies. J Virol 1999, 73(9):7734-7744.

42. Peeters M, Janssens W, Fransen K, Brandful J, Heyndrickx L, Koffi K, Delaporte E, Piot P, Gershy-Damet GM, Van Der Groen G: Isolation of simian immunodeficiency viruses from two sooty mangabeys in Cote d'Ivoire: virological and genetic characterization and relationship to other HIV type 2 and SIVsm/mac strains. AIDS Res Hum Retrov 1994, 10: 1289-1294.

43. Allan JS, Kanda P, Kennedy RC, Cobb EK, Anthony M, Eichberg JW: Isolation and characterization of simian immunodeficiency 
viruses from two subspecies of African green monkeys. AIDS Res Hum Retrov 1990, 6:275-284.

44. Nowak MA, Anderson RM, McLean AR, Wolfs TFW, Goudsmit J, May RM: Antigenic diversity thresholds and the development of AIDS. Science 1991, 254:963-969.

45. Nowak MA, May RM: Mathematical biology of HIV infections: antigenic variation and diversity threshold. Mathematical Bioscience 1991, 106:1-21.

46. McDonald RA, Mayers DL, Chung RCY, Wagner KF, Ratto-Kim S, Birx DL, Michael NL: Evolution of human immunodeficiency virus type I env sequence variation in patients with diverse rates of disease progression and T-cell function. J Virol 1997 7I: I87I-I879.

47. Shankarappa R, Margolick J, Gange S, Rodrigo AG, Upchurch D, Farzadegan H, Gupta P, Rinaldo CRJ, Learn G, He X, Huang XL, Mullins $\mathrm{Jl}$ : Consistent viral evolutionary changes associated with the progression of human immunodeficiency virus type $I$ infection. I Virol 1999, 73:10489-10502.

48. Lambotte O, Chaix ML, Gubler B, Nasreddine N, Wallon C, Goujard C, Rouzioux C, Taoufik Y, Delfraissy JF: The lymphocyte HIV reservoir in patients on long-term HAART is a memory of virus evolution. AIDS 2004, 18:1 I47-II 58.

49. Schnittman SS, Psallidopoulos MC, Lane HC, Thompson L, M B, F M, C.H. F, N.P. S, A.S. F: The reservoir for HIV-I in human peripheral blood is a $\mathrm{T}$ cell that maintains expression of CD4. Science 1989, 245:305-308.

50. Puffer BA, Altamura LA, Pierson TC, Doms RW: Determinants within gp I 20 and gp4I contribute to CD4 independence of SIV Envs. Virology 2004, 327:16-25.

5I. Vodros D, Thorstensson R, Doms RW, Fenyo EM, Reeves JD: Evolution of coreceptor use and CD4-independence in envelope clones derived from SIVsm-infected macaques. J Virol 2003, 316:17-28.

52. Richman DD, Wrin T, Little SJ, Petropoulos CJ: Rapid evolution of the neutralizing antibody response to HIV type I infection. Proc Natl Acad Sci USA 2003, 100:4 | 44-4149.

53. Wei $X$, Decker JM, Wang $S$, Hui $H$, Kappes JC, Wu X, SalazarGonzalez JF, Salazar MG, Kilby JM, Saag MS, Komarova N, Nowak MA, Hahn BH, Kwong PD, Shaw GM: Antibody neutralization and escape by HIV-I. Nature 2003, 422:307-3II.

54. Derdeyn CA, Decker JM, Bibollet-Ruche F, Mokili JL, Muldoon M, Denham SA, Heil ML, Kasolo F, Musonda R, Hahn BH, Shaw GM, Korber BT, Allen S, Hunter E: Envelope-constrained neutralizationsensitive HIV-I after heterosexual transmission. Science 2004 303(5666):2019-2022.

55. Kalish ML, Korber BT, Robbins KE, Leo YS, Saekhou A, Verghese I, Gerrish P, Goh CL, Lupo D, Tan BH, Brown TM, Chan R: The sequential introduction of HIV-I subtype $B$ and CRFO I_AE in Singapore by sexual transmission: accelerated $V 3$ region evolution in a subpopulation of Asian CRFOI viruses. Virology 2002, 304:3II-329.

56. Muller-Trutwin MC, Corbet $S$, Tavares MD, Herve VMA, Nerrienet E, Georges-Courbot MC, Saurin W, Sonigo P, Barre-Sinoussi F: The evolutionary rate of nonpathogenic simian immunodeficiency virus (SIVagm) is in agreement with a rapid and continuous replication in vivo. Virology 1996, 223:89-102.

57. Rey-Cuille MA, Berthier JL, Bomsel-Demontoy MC, Chaduc Y, Montagnier L, Hovanessian AG, Chakrabarti LA: Simian immunodeficiency virus replicates to high levels in sooty mangabeys without inducing disease. J Virol 1998, 72(5):3872-3886.

58. Baier M, Dittmar MT, Cichutek K, Kurth R: Development in vivo of genetic variability of simian immunodeficiency virus. Proc Natl Acad Sci USA I99I, 88:8126-8I30.

59. Johnson PR, Fomsgaard A, Allan JS, Gravell M, London WT, Olmsted RA, Hirsch V: Simian immunodeficiency viruses from African green monkeys display unusual genetic diversity. J Virol 1990, 64:1086-1092

60. Norley SG: SIVagm infection of its natural African geen monkey host. Immunol Lett 1996, 51:53-58.

61. Kurth R, Norley S: Simian immunodeficiency viruses of African green monkeys. Curr Top Microbiol Immunol 1994, 188:2 I-33.

62. Goldstein S, Ourmanov I, Brown CR, Beer BE, Elkins WR, Plishka R, Buckler-White A, Hirsch V: Wide range of viral load in healthy African green monkeys naturally infected with simian immunodeficiency virus. J Virol 2000, 74: | I744- I I 753.
63. Broussard SR, Staprans SI, White R, Whitehead EM, Feinberg MB, Allan JS: Simian immunodeficiency virus replicates to high levels in naturally infected african green monkeys without inducing immunologic or neurologic disease. I Virol 200I, 75:2262-2275.

64. Masciotra S, Owen SM, Rudolph D, Yang C, Wang B, Saksena NK Spira T, Dhawan S, Lal RB: Temporal relationship between VIV2 variation, macrophage replication, and coreceptor adaptation during HIV-I disease progression. AIDS 2002, 16:1887-1898.

65. Palmer C, Balfe P, Fox D, May JC, Frederiksson R, Fenyo EM, McKeating JA: Functional characterization of the VIV2 region of human immunodeficiency virus type I. Virology 1996, 220:436-449.

66. Valli PJS, Lukashov VV, Heeney JL, Goudsmit J: Shortening of the symptom-free period in rhesus macaques is associated with decreasing nonsynonymous variation in the env variable regions of simian immunodeficiency viurs SIVsm during passage. J Virol 1998, 72(9):7494-7500.

67. Poss M, Rodrigo AG, Gosink J], Learn GH, De Vange Pateleeff D, Martin HLJ, Bwayo J, Kreiss JK, Overbaugh J: Evolution of envelope sequences from the genital tract peripheral blood of women infected with clade $\mathbf{A}$ human immunodeficiency virus type $\mathbf{I}$. J Virol 1998, 72(10):8240-825।

68. Shankarappa R, Gupta P, Learn GHJ, Rodrigo AG, Rinaldo CRJ, Gorry MC, Mullins JI, Nara PL, Ehrlich GD: Evolution of human immunodeficiency virus type I sequences in infected individuals with differing disease progression profiles. Virology 1998, 24I:25I-259

69. Courgnaud V, Laure F, Fultz PN, Montagnier L, Brechot C, Sonigo P: Genetic differences accounting for evolution and pathogenicity of simian immunodeficiency virus from a sooty mangabey monkey after cross-species transmission to a pigtailed macaque. J Virol 1992, 66:4|4-419.

70. Fomsgaard A, Johnson PR, London WT, Hirsch V: Genetic variation of the SIVagm transmembrane glycoprotein in naturally and experimentally infected primates. AIDS 1993, 7:104I-1047.

7I. Ondoa P, Davis D, Willems B, Heyndrickx L, Kestens L, van der Berg I, Coppens S, Janssens W, Heeney J, Van Der Groen G: Genetic variability of the VI and V2 env domains of SIVcpz-ant and neutralization pattern of plasma viruses in a chimpanzee infected naturally. J Med Virol 200I, 65:765-776.

72. Silvestri G, Feinberg MB: Turnover of lymphocytes and conceptual paradigms in HIV infection. J Clin Invest 2003, I I2(6):82I-824.

73. Rodrigo A, Felsenstein J: Coalescent Approaches to HIV Population Genetics. In The Evolution of HIV Edited by: Crandall KA. Baltimore, MD , The Johns Hopkins University Press; 1999:233-274.

74. Silvestri G: Naturally SIV-infected sooty mangabeys: are we closer to understanding why they do not develop AIDS? Med Primatol 2005, 34(5-6):243-252.

75. Kantor R, Shafer RW, Follansbee S, Taylor J, Shilane D, Hurley L, Nguyen DP, Katzenstein D, Fessel W]: Evolution of resistance to drugs in HIV-I-infected patients failing antiretroviral therapy. AIDS 2004, I8:I503-I5II.

76. Wyatt R, Kwong PD, Desjardins E, Sweet RW, Robinson J Hendrickson WA, Sodroski J: The antigenic structure of the HIVgp I 20 envelope glycoprotein. Nature 1998, 393:705-7II.

77. Kunstman KJ, Puffer B, Korber BT, Kuiken C, Smith UR, Kunstman J, Stanton J, Agy M, Shibata R, Yoder AD, Pillai S, Doms RW, Marx P, Wolinsky SM: Structure and function of CC-chemokine receptor 5 homologues derived from representative primate species and subspecies of the taxonomic suborders Prosimii and Anthropoidea. / Virol 2003, 77(22): |23|0-123|8.

78. Fomsgaard A, Hirsch VM, Johnson PR: Cloning and sequences of primate CD4 molecules: diversity of the cellular receptor for simian immunodeficiency virus/human immunodeficiency virus. Eur J Immunol 1992, 22:2973-298 I.

79. Farci P, Strazzera R, Alter HJ, Farci S, Degioannis D, Coiana A, Peddis G, Usai F, Serra G, Chessa L, Diaz G, Balestrieri A, Purcell RH: Early changes in hepatitis $C$ viral quasispecies during interferon therapy predict the therapeutic outcome. Proc Natl Acad Sci USA 2002, 99(5):308I-3086

80. Bowen DG, Walker CM: The origin of quasispecies: cause or consequence of chronic hepatitis $\mathbf{C}$ viral infection? Journal of Hepatology 2005, 42:408-4I7. 
8I. Los Alamos HIV Databases, http://www.hiv.lanl.gov/. .

82. Rodrigo AG, Hanley EW, Goracke PC, Learn GHJ: Sampling and processing HIV molecular sequences: a computational evolutionary biologist's perspective. In Computational and evolutionary analysis of HIV molecular sequences Edited by: Rodrigo AG, Learn $\mathrm{GH}$. Boston, Kluwer Academic Publishers; 200 I: I-18.

83. Thompson JD, Higgins DG, Gibson TJ: CLUSTAL W: improving the sensitivity of progressive multiple sequence alignment through sequence weighting, position-specific gap penalties and weight matrix choice. Nucleic Acid Res 1994, 22:4673-4680.

84. Maddison WP, Maddison DR: Interactive analysis of phylogeny and character evolution using the computer program MacClade. Folia Primatol 1989, 53(I-4): 190-202.

85. Hall HT: BioEdit: a user-friendly biological sequence alignment editor and analysis program for Windows 95/98/NT. Nucl Acids Symp Ser 1999, 41:95-98.

86. McAllister J, Casino C, Davidson F, Power J, Lawlor E, Yap PL, Simmonds P, Smith DB: Long-term evolution of the hypervariable region of hepatitis $C$ in a common-source-infected cohort. J Virol 1998, 72(6):4893-4905.

87. Posada D, Crandall KA: Modeltest: testing the model of DNA substitution. Bioinformatics 1998, I4(9):817-818.

88. Jobb G: Treefinder. Munich, Germany, www.treefinder.de; 2002.

89. $\mathrm{Gu} X, \mathrm{Li} W \mathrm{H}$ : A general additive distance with time-reversibility and rate variation among nucleotide sites. Proc Natl Acad Sci USA 1996, 93:467I-4676.

90. Gu X, Li WH: Estimation of evolutionary distances under stationary and nonstationary models of nucleotide substitution. Proc Natl Acad Sci USA 1998, 95:5899-5905.

91. Yang Z: Estimating the pattern of nucleotide substitution. J Mol Evol 1994, 39(I): I05-III.

92. Nei M, Gojobori T: Simple methods for estimating the numbers of synonymous and nonsynonymous nucleotide substitutions. Mol Biol Evol 1986, 3(5):418-426.

93. Ota T, Nei M: Variance and covariances of the numbers of synonymous and nonsynonymous substitutions per site. Molecular Biology and Evolution 1994, I I (4):6I3-6I9.

94. Tamura K, Nei M: Estimation of the number of nucleotide substitutions in the control region of mitochondrial DNA in humans and chimpanzees. Mol Biol Evol 1993, 10:512-526.

95. Kumar S, Tamura K, Nei M: Molecular Evolutionary Genetic Analysis. 2.0th edition. University Park, Pennsylvania ; 2000.

96. Kumar S, Tamura K, Jakobsen I, Nei M: MEGA2: molecular evolutionary genetics analysis software. Bioinformatics 200I, 17:1244-1245

97. Ihaka R, Gentleman R: R: A language for data analysis and graphics. J Comput Graph Stat 1996, 5:299-314.

\section{Publish with Bio Med Central and every scientist can read your work free of charge}

"BioMed Central will be the most significant development for disseminating the results of biomedical research in our lifetime. "

Sir Paul Nurse, Cancer Research UK

Your research papers will be:

- available free of charge to the entire biomedical community

- peer reviewed and published immediately upon acceptance

- cited in PubMed and archived on PubMed Central

- yours - you keep the copyright
BioMedcentral 